\title{
Gümrük Birliği Antlaşmasını Takip Eden Süreçte Türkiye-BRICS Dış Ticareti Yoğunlaşma Analizi
}

\author{
Dr. Nurdan KUŞAT \\ Süleyman Demirel Üniversitesi, Eğirdir MYO, ISPARTA
}

\begin{abstract}
ÖZET
Gümrük Birliği Antlaşması, Türkiye-Avrupa Birliği arasında kısmi oranlı bir ekonomik entegrasyonun sağlanmasına aracılık etmiştir. Bu entegrasyonun ilk yıllarında AB ile gerçekleştirilen ticari ilişkiler Türk ekonomisi için önemli bir ă̆ırlığa sahip olmuştur. Oysa günümüzde Türkiye'nin dış ticaretinde AB'nin payının zamanla azaldiğ gözlenmektedir. Bu bağlamda GB Antlaşması sonrası Türkiye-BRICS arasındaki ürün ve ülke bazlı yoğunlaşmanın analiz edildiği bu çalı̧̧mada Türkiye İstatistik Kurumu'nun verilerinden yararlanılmıştır. Çalışma sonucunda; GB Antlaşması sonrası; ülke bazlı ticari yoğunlaşmanın Rusya'dan Çin'e doğru kaydı̆̆ gözlenmiştir. İhracattaki ürün bazlı yoğunlaşmanın sadece "Akaryakıt Hariç Yenilmeyen Hammaddeler" $(\% 54,8)$ ürün grubunda oluşurken, ithalattaki yoğunlaşmanın "Mineral Yakıtlar, Yağlar ve Benzeri Damitılmasından Elde Edilen Ürünler" (\%35,3), "Çeşitli Mamul Eşya" (32,2) ve "Hayvansal, Bitkisel Katı ve Sıvı Yağlar, Mumlar (\%30,5) isimli ürün gruplarında gerçekleştiği tespit edilmiştir.
\end{abstract}

Anahtar Kelimeler: Ticari Yoğunlaşma, Dış Ticaret, BRICS Ülkeleri, Türkiye, Gümrük Birliği.

JEL Sinıflaması: F14, F15.

Analysis of Concentration of Foreign Trade between Turkey and BRICS during the Period Following the Customs Union Agreement

ABSTRACT

Customs Union Agreement served as an intermediary for ensuring the partial economic integration between Turkey and the EU. During the initial years of this integration, the trade relations with the European Union had a significant role in the Turkish economy. However, it can nowadays be observed that the EU's share in Turkey's foreign trade is gradually diminishing. In this context, this study, which analyzes the concentration of trade between Turkey and BRICS in the post-CU period based on products and countries, benefited from the data provided by the Turkish Statistics Institution. As a result of the study, it was observed that the country-based trade intensification moved from Russia to China after the ratification of the CU Agreement. It was determined that the product-based concentration in exportation occurred only within the product group named "Crude Materials, Inedible, Except Fuels" (54.8\%), whereas the concentration within importation occurred in the product groups named "Mineral Fuel, Lubricants and Related Materials" (35.3\%), "Miscellaneous Manufactured Articles" (32.\%) and "Animal and Vegetable Oils, Fats and Waxes" (30.5\%). Union.

Key Words: Trade Concentration, Foreign Trade, BRICS Countries, Turkey, Customs

JEL Classification: F14, F15.

\section{Giriş}

Türkiye ekonomisinin tarihi gelişimi içersinde 24 Ocak Kararları ve Gümrük Birliği (GB) Antlaşması özel bir öneme haizdir. 24 Ocak 1980 itibariyle 
liberal politikaların dış ticareti yönlendirmeye başlamasıyla Türkiye dış ticareti bir dönüm noktasına girmiştir. 1996'daki GB süreci sonrası entegrasyon içi gümrük vergilerinin sıfırlanması dış ticareti bir kez daha değişime maruz bırakmıştır.

Türkiye dış ticaretindeki bu liberal dönüşümün hem diş ticarete konu olan malların yapısını, hem de dış ticaret ortaklarını bir şekilde etkilemesi olasıdır. Sonuç itibariyle bu yönde bir takım gelişmeler de ortaya çıkmıştır. Bu gelişmelerin en önemli sonucu artan dış ticaret hacmi olarak kendisini gösterirken, olumsuzluk artan dış ticaret açıkları şeklinde olmuştur.

Bu çalışmada amaç; Türkiye-Avrupa Birliği (AB) ilişkilerinin yeni bir boyut kazandığı 1996 GB Antlaşması sonrasında Türkiye'nin AB ile ticari ilişkilerinden ziyade, yükselen ekonomiler olarak tanınan ve 2001'den itibaren BRICS olarak isimlendirilen ülkeler ile olan ticari ilişkilerini değerlendirmektir. $\mathrm{Bu}$ değerlendirme öncelikle TÜIK' in resmi internet sitesinden yararlanılarak oluşturulan tabloların ve bu tabloları daha anlamlı kıldığı düşünülen tarafımızdan hesaplanmış oranların yorumlanmasıyla gerçekleştirilmektedir. Fakat öncesinde AB-BRICS ticari ilişkilerine de kısaca değinilmektedir. Türkiye-BRICS ticaretinde yaşanan ticaret yaratıcı ve ticaret saptırıcı etkilerin ülke bazlı yoğunlaşma etkilerinin değerlendirilmesinin yanı sıra, SITC Rev3 Düzey 1 sınıflamasında yer alan ürün gruplarına göre ürün bazlı ticari yoğunlaşma da bu çalışma çerçevesinde ele alınmaktadır.

$\mathrm{Bu}$ bağlamda; makalenin içeriği şu şekilde oluşturulmuştur: Yapılacak çalışmanın genel amacının kısaca özetlendiği ve çalışmada kullanılacak metodun belirtildiği giriş bölümünün ardından, birinci bölümde ekonomik entegrasyonların ve özellikle GB anlaşmalarının üye ve üçüncü ülkelerin dış ticaretlerine statik etkileri değerlendirilmektedir. İkinci bölümde BRICS ülkeleri tanıtılmakta ve Türkiye ile bu ülkeler arasındaki benzerlik ve farklılıklar ortaya konulmaktadır. $\mathrm{Bu}$ bölümü dış ticarette yoğunlaşmanın kavramsal olarak tanımlandığı, ABBRICS ticaretindeki son dönem açısından gelişimin değerlendirildiği ve TürkiyeBRICS ticaretindeki ülke ve ürün bazlı yoğunlaşma yapısının ortaya konulduğu üçüncü bölüm takip etmektedir. Çalışma elde edilen bulguların yorumlandığı sonuç bölümü ile tamamlanmaktadır.

\section{EKONOMIK ENTEGRASYONLAR VE STATIK ETKILERI}

"Ekonomik Entegrasyon" kavramı kapitalist sistemin baskıları ve liberal dış ticaret anlayışının genel kabulü ile uluslararası iktisat literatürüne girerek, küresel ekonomik düzene yeni bir boyut kazandırmıştır. Ekonomik entegrasyonlarda temel amaç; dünya ticaretini kısıtlayıcı her türlü engelin kaldırılması ve dış ticaret yerine gittikçe yaygınlaşan bölgesel ve küresel ticaret olgusunun yerleştirilmesidir.

Balassa (1961:21) ekonomik entegrasyonları dört grup altında toplamaktadır: (1) Serbest Ticaret Bölgesi, (2) Gümrük Birliği, (3) Ortak Pazar ve (4) Ekonomik ve Parasal Birlik. Karluk (2013:284) ise GATT/GATTS kapsamında beş ekonomik entegrasyon türü olduğunu belirtmekte ve yukarıda 
sayılan entegrasyonların en başına Tercihli Ticaret Antlaşmaları'nı yerleştirmektedir.

Ülkelerin ekonomik bir entegrasyon oluşturmaları durumunda ülke içi fiyatların değişmesiyle üretim ve tüketim kalıplarında meydana gelen değişmeler dış ticaret kalıplarını da değiştirecektir. $\mathrm{Bu}$ değişiklikler ülkenin sadece entegrasyon oluşturduğu ülkelerle olan ticaretini değil, entegrasyon dişı ülkelerle olan ticaretini de etkileyecektir.

Kösekahyaoğlu (2012:106) ekonomik entegrasyonlar sonrası mevcut teknoloji seviyesinin ve ekonomik yapının sabit kaldığı varsayımı altında, kaynakların yeniden dağılımı nedeniyle ortaya çıkan etkilerin statik etkiler olduğunu belirtir. Entegrasyon sonrası bir defaya mahsus olmak üzere, entegrasyona giren ülkelerde ortaya çıkan bu etkiler; (1) Üretim Etkileri, (2) Tüketim Etkileri ve (3) Ticaret Hadlerindeki Etkiler olmak üzere üçe ayrılırlar (Çelik, 2012:441). Üretim ve tüketim etkileri aynı zamanda potansiyel refah etkileri olup (Karluk, 2013:289) ticaret yaratıcı ve ticaret saptırıcı etkilerle entegrasyon üyesi ülkelerin ekonomik verileri üzerinde önemli rol oynamaktadır.

GB ekonomik entegrasyon türlerinden bir tanesidir. $\mathrm{Bu}$ entegrasyon sonucunda da entegrasyona dahil olan ülkeler arasında ticaret yaratıcı ve ticaret saptırıcı bir takım etkilerin gelişmesi aşikardır. Ticaret yaratma etkisinde birlik içi ticaretin artan boyutu olumlu olarak değerlendirilirken, ticaret saptırma etkisinde birlik dışı ticaretin azalan boyutu olumsuz olarak değerlendirilmektedir. Seyidoğlu (2003:206) bu durumu, bölge dişına ortak gümrük tarifeleri uygulanmasının bölge içi ticareti geliştirirken, bölge dışı ticareti etkileme kabiliyeti olarak değerlendirir.

$\mathrm{Bu}$ etkilerin genellikle birlik dışında kalan ülkelerle birlik üyesi ülkeler arasındaki ticareti azaltıcı yönde gelişmeler yaratacağı genel kabulü yaygın olsa da; Karluk'un (2013:323) da belirttiği gibi genellikle oluşturulan entegrasyonun yeterince büyük olmaması ve bazı hammaddelerde dışa bağımlılı̆̆ın devam ediyor olması bu etkinin gücünü azaltmaktadır (Karluk, 2013:323).

Türkiye'nin AB ile gerçekleştirdiği GB çerçevesinde ortaya çıkan ticaret yaratıcı ve ticaret saptırıcı etkilerin incelendiği çalışmalarda birbiriyle çelişen bazı farklı sonuçlara rastlanmaktadır.

Morgil'in (2000) çalışma sonuçları GB'nin sınırlı miktarda ticaret yaratıcı etki ortaya çıkardığını ve Türkiye için ticaret saptırıcı etkilere yol açmadığını ortaya koyarken; Kızıltan ve arkadaşlarının (2008) çalışma sonuçları da GB'ye girişten sonraki 10 yıllık süreçte Birliğin Türkiye dış ticaretini artırıcı etkiler yarattığını göstermektedir. Çolpan Nart'da (2010) benzer bir çalışmada GB'nin ticaret yaratıcı etkiler ortaya çıkardığı sonucuna ulaşmıştır. Bu çalışmalar GB sonrası birlik içerisinde ticaret yaratıcı etkilerin geliştiğini gösteren çalışmalardır.

Togan (2000) yapmış olduğu çalışma ile Türkiye’nin Birliğe dahil olmasıyla AB'ye olan ihracatının önemli oranda değişmediği ve AB'den yapılan ithalatın artış oranının, AB dışından yapılan ithalat artış oranından daha yüksek olduğu sonucuna varmıştır. Çak ve Çak (2007) ise çalışmalarında Birlik üyeliğinin ihracatın yıllık artış hızı üzerinde anlamlı pozitif bir ilişki yaratmadığı, 
üçüncü ülkelerden olan ithalatı artırdığı yönünde bulgular elde etmişlerdir. Gündüz ve Esengün'de (2007) benzer bir çalışmada Türkiye'nin ithalat değerlerindeki artışın, ihracattan daha yüksek olduğunu tespit etmişlerdir. Temiz'in (2009) çalışması ise GB sonrasında Türkiye'nin ticaret hacminde artış olmasına rağmen net ihracatta düşüş olduğunu göstermektedir. Kalaycı ve Artan (2010) çalışmalarında GB'nin Türkiye'nin AB ile olan ihracatını ve AB ülkelerinin birlik içi ticaretini artırdığı, fakat Türkiye'nin ihracat artışının Birlik içi ticaretten daha az arttı̆̆ sonucuna varmışlardır. Gökdemir ve Karaman (2008) da çalışmalarında AB'nin Türkiye'nin net refahı üzerindeki etkisinin kısıtlı olduğu sonucuna varmaktadır.

\section{TÜRKIYYE - BRICS ÜLKELERİ BENZERLİ̆̈̇}

Küresel dünyanın yükselen ekonomileri olarak gösterilen BRICS ülkeleri günümüz ve gelecek için önemli bir ekonomik potansiyel ortaya koymaktadır. İlk olarak BRIC adıyla 4 yükselen ekonomiyi temsil eden bu tanımlama, son yıllarda yanına 5. ekonomik gücü de alarak BRICS ismiyle adlandırılmaya başlamıştır. BRICS; Brezilya, Rusya, Hindistan, Çin ve Güney Afrika ülkelerinin İngilizce yazılımındaki ülke adlarının baş harflerinden oluşan bir kısaltmadır. BRIC terimi ilk kez 2001 y1lında bir kurumsal yatırım şirketi olan Goldman Sachs tarafindan kullanılmış ve 2003 yılında hazırlanan bir raporda da BRIC'in hala dünyanın gelişmekte olan dört büyük ülkesi olduğuna, bunun yanı sıra Güney Afrika'nın da ekonomik potansiyeline dikkat çekilmiştir (Wilson and Purushothaman, 2003:11).

Simon (2011:7) BRIC ülkelerinin küresel büyümenin en önemli itici gücü olduğunu ifade ederken; bu durumu BRIC ülkelerinin ekonomik krizden çok daha az etkilenmesi ve çok daha kısa sürede kendisini toplayabilme yeteneğiyle açıklamaktadır. Canela, Collazo \& Santiso (2006:2) ise bu ülkelerin son yıllarda OECD içerisinde yer alan tüm ülkelerden daha hızlı bir şekilde büyüdüğüne dikkat çekmektedir. Standard \& Poors (2009:2) da bu ülkelerin ekonomik performanslarının geçmiş yıllara ait ortalama değerleri aştı̆̆ını ve yabancı sermaye yatırımlarında da önemli gelişmeler kaydettiklerini belirtmektedir.

$\mathrm{Bu}$ ülkelerin büyümelerinde rol oynayan iç ve diş dinamikler birbirinden farklıdır. Çin ve Hindistan'ın önemli miktarda beşeri sermayeye sahip olduğu aşikardır. Brezilya ise, içinde yer aldığı bölgede zengin doğal kaynaklara sahip bir ülke olarak dikkat çekerken, Rusya zengin doğal kaynakların yanı sıra kalifiye beşeri sermayesi ile geleceğe yön verebilecek bir ekonomik potansiyele sahiptir (Hitt, Li \& Worthington, 2005:355). Aslında BRIC ülkelerini dünya ekonomisine entegre olma konusunda mükemmel kılan güç bu ülkelerin ekonomik potansiyellerinin çeşitliliğidir (O'Neill et al, 2005:3). Hatta BRICS ülkelerinin gelecekte G7'lerin ekonomik liderliğini elinden alabileceği yönünde bir takım tartışmalara da rastlanmaktadır (Frank and Frank, 2010:46-54).

Türkiye, BRICS ülkeleri arasında yer alması muhtemel olan ülkelerden birisi olarak gösterilmektedir (Altundal, 2014:35). Hatta Türkiye'nin 1999 ve 2001 yılında yaşadığ 1 krizler sonrasında göstermiş olduğu performans, dönemin İngiltere Başbakanı David Cameron tarafından takdir edilmiş ve Türkiye'nin AB'nin BRIC'i olarak tanımlanmasının uygun olacağı belirtilmiştir (Schiller, 
2011:28). Bu nedenledir ki Türkiye'nin küresel ekonomiler içerisindeki yeri ve BRICS ülkeleriyle olan ticari ilişkileri gün geçtikçe daha fazla önem kazanmaktadır.

\section{TICCARI YOĞUNLAŞMA VE AB-TÜRKIYE-BRICS TICARİ ÍLIŞKILERI}

\section{A. Ticari Yoğunlaşma}

Dış ticarette yoğunlaşma kavramı, bir ülkenin dış ticaretinde meydana gelen sektörel (ürün) ve ülke bazlı değişmelerin değerlendirilmesi amacıyla kullanılmaktadır. Bu kavramın diş ticaret açısından önem kazanmaya başlaması ise dünya ülkeleri arasındaki ilişkilerin liberal bir yapıya kavuşması, diğer bir ifadeyle, küreselleşme ile mümkün olmuştur. Dış ticaret anlayışında meydana gelen bu değişim ülkelerin dış ticaret hacimleri üzerinde etkiler yaratırken, aynı zamanda ülkelerin ürün ve ülke tercihlerini de farklılaştırmıştır. Yıldız ve Delice (2001) liberal politikalar sayesinde artan ihracat ile ülke büyümesinde olumlu gelişmeler elde edilirken, ülke ve ürün portföyünde meydana gelen değişmeler sayesinde de büyüme hızının artacağını öngörmektedir. Bu açıdan bakıldığında; ticari yoğunlaşmanın dış ticaretin olumlu ekonomik etkilerini ortaya çıkaran özel bir yapı ortaya koyduğu ifade edilebilir.

Liberal dış ticaret anlayışını benimseyerek kalkınma politikalarını şekillendiren ekonomiler için ticari yoğunlaşma düzeyi oldukça büyük önem arzeder. Çünkü bu tür ekonomilerin ihracat gelirleri az sayıda sektöre ve/veya ülkeye bağlı olarak oluşuyorsa, bu malların fiyatlarındaki dalgalanmalar ve dış talepte meydana gelen daralmalar ihracat gelirlerinin azalmasina ve ekonomik istikrarsızlığa sebep olabilecektir (Küçükkiremitçi vd., 2010:2). Bu durumun tersi yönünde bir gelişmenin de olabileceği ve bu durumda sonuçların ülke ekonomisi açısından olumlu olacağı da unutulmamalıdır. İşte bu önem ticari yoğunlaşmanın sebeplerinin ve nelerden etkilendiğinin araştırılmasını zorunlu kılmaktadır.

Krugman'ın (1986) çalışma sonuçları ülkelerin teknolojik yenilik üretme kapasitesi ile ülke ihraç malı çeşitliliği arasında pozitif yönlü bir ilişkinin varlığını ortaya koymaktadır. Lall (2000) ise çalışmasında; yabancı sermaye yatırımlarının özellikle gelişmekte olan ülkeler üzerinde ihracat ürün çeşitliliğini artırıcı etki yaratığına vurgu yapmaktadır. Bu bağlamda; Kösekahyaoğlu (2007:17) ülkeler arasında gözlemlenen ürün yoğunlaşma düzey farklılıklarının kaynağını dört sebebe dayandırmaktadır: (1) Ekonomik Gelişme Düzeyi, (2) Sanayileşme Düzeyi, (3) Ülkenin Coğrafi Konumu ve (4) Ekonomik Büyüklük.

Ticari yoğunlaşmanın kaynağı ne olursa olsun tüm yaşanan gelişmelerin liberal dış ticaret anlayışının yaygın kabulü ile hayat bulduğu aşikardır. $\mathrm{Bu}$ bağlamda da; Türkiye için bu kavramın 1980 sonrası dönemde anlam kazanmaya başladığını ve Türkiye kaynaklı ticari yoğunlaşma analizlerinin de bu tarih sonrasında yapılmaya başlandığını söyleyebiliriz. Falcığlu ve Akgüngör'ün (2005:15) Türk imalat sektöründeki yoğunlaşma analizi sonuçları, Türk imalat sanayinin 1980-2000 yılları arasında hem ürün hem de bölge bazlı yoğunlaşma sürecine girdiğini göstermektedir. Diş ticarette yoğunlaşma olarak kendisini gösteren bu gelişmelerin ihracata yönelik üretilen mal ve hizmet türleri üzerinde 

değiştirici bir etki yaratabileceği düşünülebilir. Nitekim Ertekin (2005:2-5) liberal dış ticaret anlayışı çerçevesindeki uygulamaların ihraç ürünlerinin üretim kompozisyonunu değiştirdiğine değinmektedir.

Akal'ın (2008:271) Ortadoğu sınır ülkeleriyle Türkiye arasındaki ticari yoğunlaşmayı analiz ettiği çalışma sonuçları, bu ülkelerle diş ticarette bazı sanayi mallarında endüstri içi ticaretin oluşmaya başladığı ve bu durumun ülke ekonomilerine olumlu yansımaları olduğu yönünde göstergelere sahiptir.

Kösekahyaoğlu (2007:15) 1980-2005 yıllarını kapsayan Türkiye dış ticaretindeki ürün ve ülke bazlı yoğunlaşmayı incelediği çalışmada; Türkiye ihracatının 80'lerden itibaren ürün bazlı bir çeşitlenmeye girdiği ve 96 yılında GB sonrasında da Türkiye ithalatının ürün yapısında küçük çaplı değişimlere rağmen, ihracatında çok önemli değişimler yaşandığı sonucuna varmaktadır.

Doğan ve Kaya (2011:17) 1996-2009 dönemini kapsayan çalışmalarında; GB sonrasında Türkiye-AB arasındaki ticarette ülke bazlı yoğunlaşmada bir değişim olmadığı, ürün bazında ise ihracatta yapısal bir değişim olmasına rağmen ithalatta AB'ye bağımlılığın azalması yönünde yapısal bir değişim gerçekleşmediği sonucuna varmaktadır.

Seymen'in (2009:199) gerçekleştirdiği benzer bir çalışma ise; AB ülkelerinin Birliğe üyelik süreçlerinin Türkiye-AB ticaretinin ülke yoğunluğunu daha çok etkilediği ve GB'nin etkilerinin bu anlamda sınırlı kaldığını ortaya koymaktadır.

Atabay Bayraktar'a (2012:412) ait çalışma, Türkiye'nin BRIC ülkeleriyle olan dış ticaretinde ülkelerin GSYH'ları, nüfusları ve aralarındaki mesafeyi anlamsız olarak değerlendirirken, ithalat ve ihracat değişkenlerinin anlamlı ve ticaret hacmini artırıcı etkide bulunduğunu ortaya koymaktadır.

Erkan'ın (2012:126-127) 1993-2010 yıllarını kapsayan çalışma sonuçları; BRIC ekonomilerinin genel olarak hammadde ve emek yoğun ürünlerin ihracatında, Türkiye'nin ise daha çok emek ve sermaye yoğun ürünlerin ihracatında uzmanlaştığını göstermektedir.

\section{B. AB-BRICS Ticari İlişkileri}

BRICS ülkelerinin içinde bulunduğumuz yüzyılda ortaya koydukları ekonomik performansın yanı sıra nüfus büyüklüğü ve dünyada kapladığı hacimsel alan da oldukça dikkat çekicidir. Dünya nüfusunun $\% 40$ ' 1 , dünya karasal büyüklüğünün $\% 25^{\prime}$ i bu ülkelere ait olduğu gibi; dünya döviz rezervlerinin \%43'ü de bu ülkeler tarafindan kontrol edilmekte ve bu pay her geçen gün artmaktadır (Van Agtmael, 2012:76). Dünya toplam GSYH'sinin yaklaşık \%27'si de bu ülkeler tarafindan yaratılmaktadır (Srinivasan, 2014). Ayrica bu ülkeler gelecek 10 yıla dair tahminler çerçevesinde büyümeye devam edecektir (Wilson vd., 2010:1). Bir başka açıdan bakıldığında ise, bu ülkelerin sadece iş ve ticaret alanında birlikte çalışmadıkları ve dünya politikasında da söz sahibi olmak istedikleri dikkat çekmektedir (Zhitao, 2011). Fakat BRICS'in bu yüksek performansına rağmen, bu ülkeler arasındaki ilişkiler, ticari serbestleşmenin tam olarak gerçekleştirilememesi nedeniyle, zannedildiği kadar derin değildir (Yu, 2014:1247). 
Tüm dünya ekonomileri için oldukça önemli bir ticari partner statüsündeki BRICS ülkeleri, AB ülkeleri için de büyük bir öneme sahiptir. Fakat AB ülkeleri BRICS ülkelerinin $A B$ ile gerçekleştirilen ticarete bir takım engellemeler getirilmesinden rahatsızlık duymakta ve AB Komisyonu'nun bu sorunun çözümü için arayış içerisinde bulunduğu dikkat çekmektedir (Borta, 2013:344). Borta (2013:345) AB-BRICS ticari ilişkilerinin gelişimini şu şekilde açıklamaktadır:

Brezilya: Latin Amerika'nın en büyük ekonomisi olan bu ülkeyle ticari ilişkiler, AB ticaretinin \%20'sini oluşturmaktadır. Ayrıca AB, Latin Amerika ülkeleri ile gerçekleştirdiği ticaretin \%37'sini Brezilya ile yapmakta ve Latin Amerika'daki yatırımlarının \%43'ü yine bu ülkede yer almaktadır.

Rusya: AB'nin ilk ticaret ortağı olan BRICS ülkesi olarak dikkat çeken bu ülke, 1997'de imzalanan bir Ortaklık ve İşbirliği Antlaşması çerçevesinde Birlik ile olan ticaretini gerçekleştirmektedir. Fakat 2008 krizi sonrasında Rusya tek taraflı korumacı tedbirlerle bu ticareti kesintiye uğratmıştır.

Hindistan: 2007 yılında AB-Hindistan Serbest Ticaret Anlaşması müzakerelerine başlanarak her iki tarafın da ticaret ve yatırım olanaklarının genişletilmesi arzulanmış ve bu çerçevede 2003-2011 yılları arasında bu ticaretin değeri 29 Milyar Euro'dan 80 Milyar Euro'ya yükseltilmiştir.

Çin: BRICS içerisinde AB'nin en büyük ticaret ortağı ve en önemli ithalat partneri olarak dikkat çekmektedir. Ülkeler arasında günde 1 Milyar Euro'luk bir ticari değer yaratımı söz konusudur. AB için ABD'nin arkasından ikinci büyük ticaret ortağı statüsüne sahip olup, bu ticaretin değeri gün ve gün yükselmektedir.

Güney Afrika: Sahraaltı Afrika ülkelerinin en güçlü ekonomisi olmasına rağmen, AB'nin Afrika'daki en büyük ticaret ortağıdır. AB-Güney Afrika arasındaki ticari ilişkilerin \%90’1 Ticaret, Kalkınma ve İşbirliği Anlaşması çerçevesinde oluşturulan Serbest Ticaret Bölgesi sayesinde gerçekleştirilmektedir.

AB'nin BRICS ülkeleriyle ticari ilişkilerindeki gelişmeleri Grafik 1 ve Grafik 2'nin yardımıyla gözlemlemek mümkündür.

Grafik 1. AB-28 Ülkelerinin BRICS'e İhracatı (Milyar Euro)

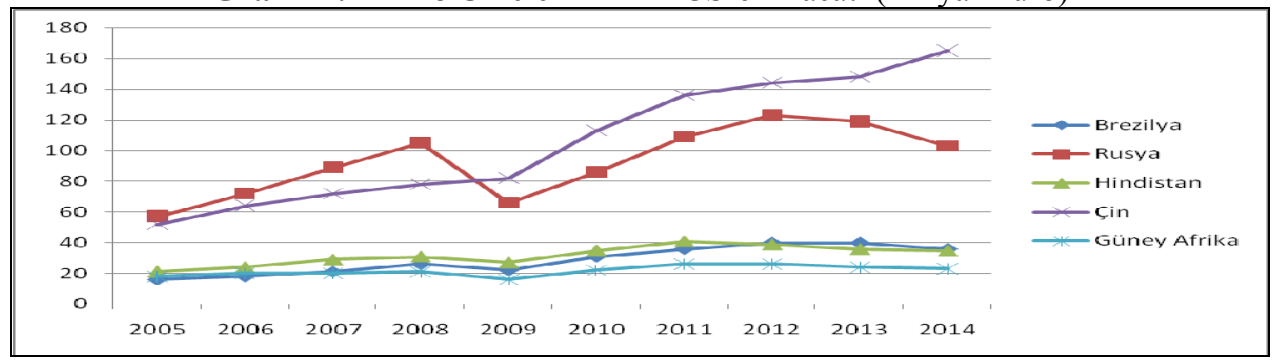

Kaynak: ec.europa.eu/eurostat/web/international_trade/data/database

AB'nin BRICS'le olan ihracatında Çin'in üstünlüğü dikkat çekmektedir. Ayrıca Çin'e gerçekleştirilen ihracatın, 2009 yılı hariç, incelen 2005-2014 aralığında sürekli arttığı da gözlenmektedir. Rusya da, Çin’den sonra AB'den en 
N. Kuşat / Gümrük Birliği Antlaşmasını Takip Eden Süreçte Türkiye-BRICS Dış Ticareti Yoğunlaşma Analizi çok mal ithal eden ülke konumundadır. 2009 yılında ithalatı azalmış olmakla birlikte, 2010'da yeniden artmaya başlamış, fakat 2012'den itibaren yeniden azalışa geçmiştir. Diğer 3 BRICS ülkesinin AB'den ithal ettikleri malların miktarındaki gelişme ise incelenen dönem için birbirine paralel bir yapı sergilemiş, 2005-2008 ve 2009-2012 dönemleri için artış, 2008-2009 dönemi ve 2012 sonrasında azalış göstermiştir.

Grafik 2. AB-28 Ülkelerinin BRICS İthalatı (Milyar Euro)

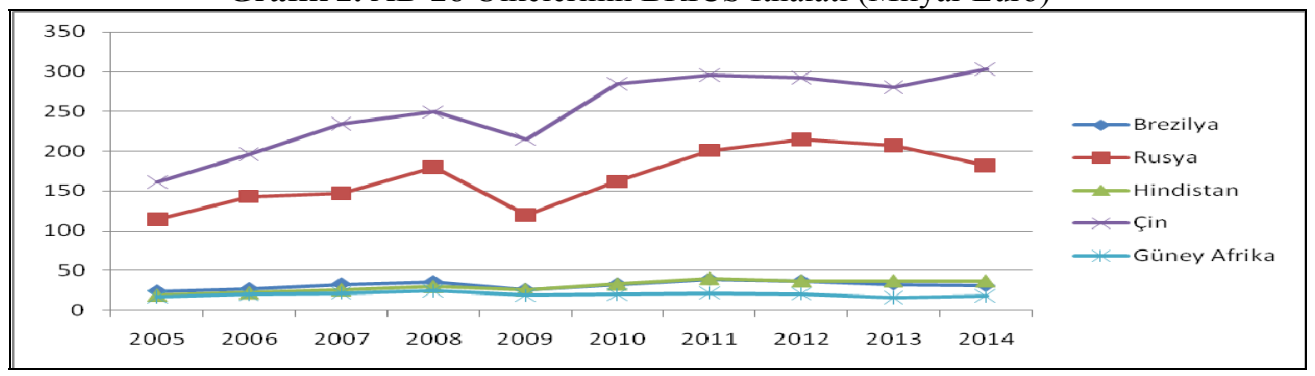

Kaynak: ec.europa.eu/eurostat/web/international_trade/data/database

AB'nin BRICS'le olan ithalatında da, ihracatta olduğu gibi, Çin'in üstünlüğ̈̈ dikkat çekmektedir. Ayrıca Çin'den gerçekleştirilen ithalatın 2009, 2012 ve 2013 yıllarında düşme gösterdiği, incelen diğer yıllarda ise sürekli arttığ 1 da gözlenmektedir. Rusya yine Çin'den sonra AB'ye en çok mal ihraç eden 2. BRICS ülkesi konumundadır. Rusya'ya olan ithalatta 2009 yılında yaşanan azalış 2012 sonrasında da kendisini göstermiştir. Diğer 3 BRICS ülkesinin AB'ye ihraç ettikleri malların miktarındaki gelişme ise, incelenen dönem için, yine birbirine paralel bir yap1 sergilemiş, krizin etkisiyle 2009'da yaşanan ihracat düşüşünü 2012'ye kadar küçük yükselişler takip ederken, sonrasında bu değer sabitlenmiştir.

Bu bağlamda; AB'nin Çin'le olan ticari ilişkileri hariç olmak üzere, küresel konjontür dalgalanmaları da hariç, diğer BRICS ülkeleriyle olan ticaretinin son yıllarda düşme eğilimine girdiği anlaşılmaktadır. Bu durum Borta (2013:358) tarafından, BRICS ülkelerinin $\mathrm{AB}$ ile gerçekleştirdikleri ticarete uyguladıkları tarife ve tarife benzeri engellemelerin bir sonucu olarak değerlendirilebilir.

\section{Türkiye-BRICS Ticari İlişkileri}

Türkiye'nin diş ticareti içerisinde BRICS ülkelerinin yerini net bir şekilde görebilmek için, öncelikle Türkiye ihracat ve ithalatında en çok paya sahip olan ilk 5 ülkenin son üç yılık ihracat ve ithalat değerlerine bakılabilir. Tablo 1 ve Tablo 2 bu amaçla düzenlenmiştir. 
Tablo 1. En Çok İhracat Yapılan 5 Ülke (2011-2013) (Bin \$)

\begin{tabular}{|c|c|c|c|c|c|c|}
\hline \multirow{2}{*}{ Ülkeler } & \multicolumn{6}{|c|}{ Yıllar } \\
\cline { 2 - 7 } & \multicolumn{2}{|c|}{$\mathbf{2 0 1 3}$} & \multicolumn{2}{c|}{$\mathbf{2 0 1 2}$} & \multicolumn{2}{c|}{$\mathbf{2 0 1 1}$} \\
\cline { 2 - 7 } & Miktar & \% & Miktar & \% & Miktar & \% \\
\hline Almanya & 13702577 & 9,0 & 13124375 & 8,6 & 13950825 & 10,3 \\
\hline Irak & 11948905 & 7,9 & 10822144 & 7,1 & 8310130 & 6,2 \\
\hline İngiltere & 8785124 & 5,8 & 8693599 & 5,7 & 8151430 & 6,0 \\
\hline Rusya Federasyonu & 6964209 & 4,6 & 6680777 & 4,4 & 5992633 & 4,4 \\
\hline İtalya & 6718355 & 4,4 & 6373080 & 4,2 & 7851480 & 5,8 \\
\hline Türkiye Toplamı & 151802637 & 100 & 152461737 & 100 & 134906869 & 100 \\
\hline
\end{tabular}

Kaynak: http://www.tuik.gov.tr/UstMenu.do?metod=temelist , erişim 11.01.2015.

Türkiye ihracatında ilk beş sırayı paylaşan ülkelerden üç tanesi AB 28 ülkesi iken (Almanya, İngiltere ve İtalya), bir tanesi BRICS ülkesidir (Rusya). Türkiye ihracatında önde gelen bu 5 ülkenin Türkiye toplam ihracatı içerisindeki pay1 2013 yılı itibariyle \%31,7; üç AB 28 ülkesinin payı \%19,2 ve bir BRICS ülkesinin payı ise \%4,6'dır. Bu paylar Türkiye ihracatı içerisinde küçük olarak gözükmekle birlikte, bu ülkelerin Türkiye ihracatında önde gelen ilk beş ülke olduğu düşünüldüğünde önem arz ettiği anlaşılmaktadır. Ayrıca bir BRICS ülkesi olan Rusya Federasyonu'nun en çok ihracat yapılan dördüncü ülke konumunda olması dikkat çekicidir.

Tablo 2. En Çok İthalat Yapılan 5 Ülke (2011-2013) (Bin \$)

\begin{tabular}{|c|c|c|c|c|c|c|}
\hline \multirow{2}{*}{ Ülkeler } & \multicolumn{6}{|c|}{ YIllar } \\
\cline { 2 - 7 } & \multicolumn{2}{|c|}{$\mathbf{2 0 1 3}$} & \multicolumn{2}{c|}{$\mathbf{2 0 1 2}$} & \multicolumn{2}{c|}{$\mathbf{2 0 1 1}$} \\
\cline { 2 - 7 } & Miktar & $\mathbf{\%}$ & Miktar & \% & Miktar & \% \\
\hline Rusya Federasyonu & 25064214 & 10,0 & 26625286 & 11,3 & 23952914 & 9,9 \\
\hline Çin & 24685885 & 9,8 & 21295242 & 9,0 & 21693336 & 9,0 \\
\hline Almanya & 24182422 & 9,6 & 21400614 & 9,0 & 22985567 & 9,5 \\
\hline İtalya & 12884864 & 5,1 & 13344468 & 5,6 & 13449861 & 5,6 \\
\hline ABD & 12596170 & 5,0 & 14130546 & 6,0 & 16034121 & 6,7 \\
\hline Türkiye Toplamı & 251661250 & 100 & 236545141 & 100 & 240841676 & 100 \\
\hline
\end{tabular}

Kaynak: http://www.tuik.gov.tr/UstMenu.do?metod=temelist , erişim 11.01.2015.

Türkiye ithalatında başta gelen beş ülkeden ilk ikisi BRICS ülkesidir (Rusya ve Çin). Üç ve dördüncü sırada yer alan ülkeler ise AB 28 ülkeleridir (Almanya ve İtalya). GB sonrasındaki durumun değerlendirilmesi açısından bakıldığında bu yapı da oldukça dikkat çekicidir. 2013 yılı itibariyle iki BRICS ülkesinden gerçekleştirilen ithalat Türkiye toplam ithalatının \%19,8'ine tekabül ederken; iki AB 28 ülkesinden gerçekleştirilen ithalat \%14,7'dir.

Tablo 1 ve Tablo 2'nin sonuçları bize Türkiye dış ticaretinde GB sonrasında da BRICS'in önemli bir yere sahip olduğunu göstermektedir. Bu önem ticaretin ithalat boyutunda kendisini daha fazla göstermektedir. Entegrasyon sonrasında bile BRICS ülkeleriyle ticari ilişkilerin yoğun olarak devam ettiği aşikardır.

Türkiye'nin GB Antlaşması sonrası BRICS ülkeleri ile gerçekleştirdiği ticaretin gelişimini istatistiki veriler yardımıyla görmek ve değerlendirmek Türkiye-BRICS ticari ilişkileri ile ilgili olarak daha anlamlı sonuçlar ortaya 
N. Kuşat / Gümrük Birliği Antlaşmasını Takip Eden Süreçte Türkiye-BRICS Dış Ticareti Yoğunlaşma Analizi koymamızda yardımc1 olacaktır. Bu amaçla düzenlenen Tablo 3'de GB sonras1 Türkiye toplam ihracatı içerisinde AB'nin, BRICS ülkelerinin ve diğer ülkelerin ihracat payları; Tablo 4'de de ithalat payları yer almaktadır.

Tablo 3. Türkiye'nin 1996-2013 Dönemi İhracatının Ülke Gruplarına Göre Dağılımı (Bin \$)

\begin{tabular}{|c|c|c|c|c|c|c|c|}
\hline \multirow[t]{2}{*}{ YILLAR } & \multirow{2}{*}{$\begin{array}{l}\text { Türkiye } \\
\text { İhracatı }\end{array}$} & \multicolumn{2}{|c|}{ AB-28 } & \multicolumn{2}{|c|}{ BRICS } & \multicolumn{2}{|c|}{ DİĞER ÜLKELER } \\
\hline & & İhracat & Pay(\%) & İhracat & Pay $(\%)^{*}$ & İhracat & Pay(\%)* \\
\hline 1996 & 23224465 & 12590475 & 54,2 & 1743182 & 7,5 & 8890808 & 38,3 \\
\hline 1997 & 26261072 & 13470875 & 51,3 & 2280825 & 8,7 & 10509372 & 40 \\
\hline 1998 & 26973952 & 14837062 & 55,0 & 1576853 & 5,8 & 10560037 & 39,2 \\
\hline 1999 & 26587225 & 15454135 & 58,1 & 838466 & 3,2 & 10294624 & 38,7 \\
\hline 2000 & 27774906 & 15688009 & 56,5 & 837639 & 3,0 & 11249258 & 40,5 \\
\hline 2001 & 31334216 & 17575678 & 56,1 & 1287671 & 4,1 & 12470867 & 39,5 \\
\hline 2002 & 36059089 & 20457907 & 56,7 & 1561971 & 4,3 & 14039211 & 39,0 \\
\hline 2003 & 47252836 & 27479360 & 58,2 & 1993747 & 4,2 & 17779729 & 37,6 \\
\hline 2004 & 63167153 & 36698919 & 58,1 & 2456444 & 3,9 & 24011790 & 38 \\
\hline 2005 & 73476408 & 41532953 & 56,5 & 3250141 & 4,4 & 31943455 & 39,1 \\
\hline 2006 & 85534676 & 48148628 & 56,3 & 4274773 & 5,0 & 33111275 & 38,7 \\
\hline 2007 & 107271750 & 60754022 & 56,6 & 6344519 & 5,9 & 40173209 & 37,5 \\
\hline 2008 & 132027196 & 63719097 & 48,3 & 8780965 & 6,7 & 59527134 & 45,0 \\
\hline 2009 & 102142613 & 47228119 & 46,2 & 5587312 & 5,5 & 49327182 & 48,3 \\
\hline 2010 & 113883219 & 52934452 & 46,5 & 8117960 & 7,2 & 52830807 & 46,3 \\
\hline 2011 & 134906869 & 62589257 & 46,4 & 10098502 & 7,5 & 62219110 & 46,1 \\
\hline 2012 & 152461737 & 59398377 & 39,0 & 11306511 & 7,4 & 81756849 & 53,6 \\
\hline 2013 & 151802637 & 63039810 & 41,5 & 12088097 & 8,0 & 76674730 & 50,5 \\
\hline $\begin{array}{l}\text { 96'dan 2013'e } \\
\text { Değişim (\%)* }\end{array}$ & 553,6 & 400,7 & $-23,4$ & 593,5 & 6,7 & 762,4 & 31,9 \\
\hline
\end{tabular}

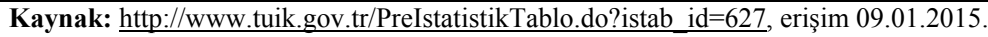

http://tuikapp.tuik.gov.tr/ , erişim 09.01.2015. * \% hesaplamaları tarafımdan yapılmıştır.

Tablo 3'ü incelediğimizde, Türkiye ihracat hacminin 1996 yılından 2013 yılına gelene kadar \%553,6 oranında arttı̆̆ını görmekteyiz. Türkiye'nin AB 28 ülkelerine olan ihracatı \%400,7 oranında artarken, BRICS ülkelerine ihracatı $\% 593,5$ oranında artmıştır. Türkiye'nin toplam ihracat hacmindeki ve incelenen ülke grupları ile olan ihracatındaki bu artışa rağmen; 1996 yılından 2013 yılına kadar AB 28'in Türkiye toplam ihracatı içerisindeki payının \%23,4 oranında gerilediği gözlenmektedir. Bu bağlamda GB sonrası ortaya çıkması beklenen ticaret yaratıcı etkiye hacimsel olarak rastlansa da, oransal olarak rastlanmadığını söylemek doğru olur.

BRICS ülkelerinin Türkiye toplam ticareti içerisindeki \% payının yıllar itibariyle \%7,5'den \%8'e yükseldiği ve \%6,7 artış gösterdiği görülmektedir. 2013 yılı itibariyle AB 28 ülkelerinin Türkiye toplam ihracatı içerisindeki payı BRICS ülkelerine oranla fazla olmakla birlikte, GB sonrası AB 28 ülkelerinin ihracat pay1 azalırken, BRICS ülkelerinin ihracat payının artması dikkat çekicidir.

Diğer taraftan 1996 yılı itibariyle AB-28 ve BRICS ile gerçekleştirilen ihracat, 1996 yılında Türkiye toplam ihracatının \%61,7'sini (\%54,2+\%7,5), 2013 y1lında ise \%49,5'ini $(\% 41,5+\% 8,0)$ kapsarken; bu durum Türkiye'nin diğer ticaret ortaklarına doğru kayan bir ihracat değeri olduğunu anlatmaktadır. \%12,2 oranındaki (değişim \%38,3'den \%50,5'e) bu artış yönlü kayma, GB'nin AB dışı ülkeler üzerinde de ticaret yaratıcı bir takım etkilerinin varlığını göstermektedir. 
Tablo 4. Türkiye’nin 1996-2014 Dönemi İthalatının Seçilmiş Ülke Gruplarına Göre Dağ 1 lımı (Bin \$)

\begin{tabular}{|c|c|c|c|c|c|c|c|}
\hline \multirow[t]{2}{*}{ YILLAR } & \multirow{2}{*}{$\begin{array}{l}\text { Türkiye } \\
\text { Ithalatı }\end{array}$} & \multicolumn{2}{|c|}{ AB-28 } & \multicolumn{2}{|c|}{ BRICS } & \multicolumn{2}{|c|}{ DİĞER ÜLKELER } \\
\hline & & İthalat & Pay(\%) & İthalat & $\operatorname{Pay}(\%)^{*}$ & İthalat & $\operatorname{Pay}(\%) *$ \\
\hline 1996 & 43626642 & 24349181 & 55,8 & 3237721 & 7,5 & 16036740 & 36,7 \\
\hline 1997 & 48558721 & 26127526 & 53,8 & 3775977 & 7,8 & 18655218 & 38,4 \\
\hline 1998 & 45921392 & 25296961 & 55,1 & 3837467 & 8,6 & 16786964 & 36,3 \\
\hline 1999 & 40671272 & 22537831 & 55,4 & 3861778 & 9,5 & 18133441 & 35,1 \\
\hline 2000 & 54502821 & 28552276 & 52,4 & 5983126 & 11,0 & 19967419 & 36,6 \\
\hline 2001 & 41399083 & 19840787 & 47,9 & 4928289 & 11,9 & 16630007 & 40,2 \\
\hline 2002 & 51553797 & 25698221 & 49,8 & 6060593 & 11,8 & 19794983 & 38,4 \\
\hline 2003 & 69339692 & 35156836 & 50,7 & 9186294 & 13,2 & 34182856 & 36,1 \\
\hline 2004 & 97539766 & 48130900 & 49,3 & 15121906 & 15,5 & 34286960 & 35,2 \\
\hline 2005 & 116774151 & 52781362 & 45,2 & 21870069 & 18,7 & 42122720 & 36,1 \\
\hline 2006 & 139576174 & 59447587 & 42,6 & 29989536 & 21,5 & 50139051 & 35,9 \\
\hline 2007 & 170062715 & 68472309 & 40,3 & 40214987 & 23,6 & 61375419 & 36,1 \\
\hline 2008 & 201963574 & 74513444 & 36,9 & 50904463 & 25,2 & 76545667 & 37,9 \\
\hline 2009 & 140928421 & 56616302 & 40,2 & 35135156 & 24,9 & 49176963 & 34,9 \\
\hline 2010 & 185544332 & 72391053 & 39,0 & 43538910 & 23,5 & 69614369 & 37,5 \\
\hline 2011 & 240841676 & 91439406 & 38,0 & 54219255 & 22,5 & 95183015 & 39,5 \\
\hline 2012 & 236545141 & 87657462 & 37,1 & 55534260 & 23,5 & 93353419 & 39,4 \\
\hline 2013 & 251661250 & 92457992 & 36,7 & 57526696 & 22,9 & 101676562 & 40,4 \\
\hline $\begin{array}{l}\text { 96'dan 2013'e } \\
\text { Değișim }(\%)^{*}\end{array}$ & 476,9 & 279,7 & $-34,2$ & 1676,8 & 205,3 & 534,0 & 10,1 \\
\hline
\end{tabular}

Kaynak: http://www.tuik.gov.tr/PreIstatistikTablo.do?istab id=1548, erişim 09.01.2015.

http://tuikapp.tuik.gov.tr/, erişim 09.01.2015. * \% hesaplamaları tarafımdan yapılmıştır.

Tablo 4 Türkiye ithalatının GB sonrası AB 28 ve BRICS ülkeleri arasındaki dağılımını göstermektedir. İthalat hacmindeki değişim açısından tabloyu değerlendirdiğimizde, hem Türkiye toplam ithalatının, hem de $\mathrm{AB} 28$ ve BRICS'e ithalatın arttığını söylemek mümkündür. Türkiye ithalatı 1996-2013 aralığında \%476,9 oranında artmıştır. GB sonrası AB 28 'den olan ithalat günümüze kadar \%279,7, BRICS'den olan ithalat ise \%1676,8 artmıştır. Bu artış değerleri GB'nin ithalat açısından ticaret yaratıcı etkisinin zayıf kaldığını göstermektedir.

AB 28 ülkelerinin 1996 'da $\% 55,8$ olan ithalat payı 2013 'de $\% 36,7$ ' ye gerilemiştir. BRICS ülkelerinden olan ithalat payı ise aynı yıllar için, \%7,5'den $\% 22,9$ 'a yükselmiştir. $\mathrm{Bu}$ açıdan bakıldığında BRICS ülkelerinden gerçekleştirilen ithalat payının 18 yılda \%205,3 artış gösterdiği ve entegrasyonun ithalat açısından da ticaret yaratıcı etkisinin kısıtlı kaldığı söylenebilir.

Bu bağlamda 1996 yılı itibariyle AB-28 ve BRICS ile gerçekleştirilen ithalat, 1996 y1lında Türkiye toplam ithalatının \%63,3'ünü (\%55,8+\%7,5), 2013 yılında ise \%59,6'sinı $(\% 36,7+\% 22,9)$ kapsamaktadır. Bu durum Türkiye'nin diğer ticaret ortaklarından $\mathrm{AB}$ ve BRICS'e doğru kayan bir ithalat değeri olduğunu göstermektedir. $\mathrm{Bu}$ azalış yönlü kayma \%3,7 oranında (değişim $\% 63,3$ 'den \%59,6'ya) gerçekleşerek, GB'nin $\mathrm{AB}$ dış1 ülkeler üzerinde ticaret saptırıcı bir takım etkilere sebep olduğunu ortaya koymaktadır.

Tablo 3 ve Tablo 4 için ortak bir değerlendirmede bulunmak gerekirse, Türkiye ile AB 28 ülkeleri arasındaki GB antlaşması entegrasyon içerisinde ticaret yaratıcı etkiler ortaya koymasına rağmen; bu gelişmeler BRICS ülkeleriyle 
N. Kuşat / Gümrük Birliği Antlaş̧masını Takip Eden Süreçte Türkiye-BRICS Dış Ticareti Yoğunlaşma Analizi olan ticareti kısıtlayıcı etkiler yaratmamış; hatta oransal anlamda Türkiye BRICS ticari ilişkilerinin GB sonrası AB 28 ülkeleriyle olan ticarete kıyasla daha da yoğunlaştığı gözlenmiştir. Fakat GB'nin, AB ve BRICS dışında kalan ülkelerle olan ihracatında ticaret yaratıcı, ithalatında ise ticaret saptırıcı etkiler doğurduğu da ortadadır.

Tablo 5. Türkiye-BRICS Dış Ticaretinin Dış Ticaret Hacmine Etkisi (Bin \$)

\begin{tabular}{|c|c|c|c|c|c|}
\hline \multirow{2}{*}{ YILLAR } & $\begin{array}{c}\text { BRICS } \\
\text { Ülkelerine } \\
\text { İhracat }\end{array}$ & $\begin{array}{c}\text { BRICS } \\
\text { Ülkelerinden } \\
\text { İthalat }\end{array}$ & $\begin{array}{c}\text { Dış Ticaret } \\
\text { Dengesi }\end{array}$ & $\begin{array}{c}\text { Dış Ticaret } \\
\text { Hacmi }\end{array}$ & $\begin{array}{c}\text { İhracatın } \\
\text { İthalatı } \\
\text { Karşılama } \\
\text { Oranı (\%) }\end{array}$ \\
\cline { 2 - 4 } & Miktar & Miktar & & & 53,9 \\
\hline $\mathbf{1 9 9 6}$ & 1743182 & 3237721 & -1494539 & 4980903 & 60,4 \\
\hline $\mathbf{1 9 9 7}$ & 2280825 & 3775977 & -1495152 & 6056802 & 41,1 \\
\hline $\mathbf{1 9 9 8}$ & 1576853 & 3837467 & -2260614 & 5414320 & 21,7 \\
\hline $\mathbf{1 9 9 9}$ & 838466 & 3861778 & -3023312 & 4700244 & 14,0 \\
\hline $\mathbf{2 0 0 0}$ & 837639 & 5983126 & -5145487 & 6820765 & 26,1 \\
\hline $\mathbf{2 0 0 1}$ & 1287671 & 4928289 & -3640618 & 6215960 & 25,8 \\
\hline $\mathbf{2 0 0 2}$ & 1561971 & 6060593 & -4498622 & 7622564 & 21,7 \\
\hline $\mathbf{2 0 0 4}$ & 1993747 & 9186294 & -7192547 & 11180041 & 16,2 \\
\hline $\mathbf{2 0 0 5}$ & 2456444 & 15121906 & -12665462 & 17578350 & 14,9 \\
\hline $\mathbf{2 0 0 6}$ & 3250141 & 21870069 & -18619928 & 25120210 & 14,3 \\
\hline $\mathbf{2 0 0 7}$ & 4274773 & 29989536 & -25714763 & 34264309 & 15,8 \\
\hline $\mathbf{2 0 0 8}$ & 8744519 & 40214987 & -33870468 & 46559506 & 17,2 \\
\hline $\mathbf{2 0 0 9}$ & 5587312 & 35135156 & -29547844 & 40722468 & 15,9 \\
\hline $\mathbf{2 0 1 0}$ & 8117960 & 43538910 & -35420950 & 51656870 & 18,6 \\
\hline $\mathbf{2 0 1 1}$ & 10098502 & 54219255 & -44120753 & 64317757 & 18,6 \\
\hline $\mathbf{2 0 1 2}$ & 11306511 & 55534260 & -44227749 & 66840771 & 20,4 \\
\hline $\mathbf{2 0 1 3}$ & 12088097 & 57526696 & -45438599 & 69614793 & 21,0 \\
\hline
\end{tabular}

Kaynak: http://www.tuik.gov.tr/UstMenu.do?metod=temelist , erişim 11.01.2015.

Türkiye-BRICS arasında gerçekleşen ticarette, bu ticari ilişkinin BRICS ülkeleri lehine bir yapı sergilediği anlaşılmaktadır. İncelenen 18 yıllık süreçte ticaret hacminin 1998, 2001 ve 2009 yılları hariç hep yükselme eğilimi gösterdiği ve 2001 ve 2009 yılları hariç dış ticaret açıklarının büyüdüğü gözlenmektedir. Açıklardaki büyüme için BRICS'den olan ithalat artışlarını sorumlu tutmak hata olacaktır. Belirtilen yıllar için ortaya çıkan daraltıcı etkilerin bazen Türkiye'nin yaşadığı krizle (1998 ve 2001), bazen de tüm dünya ekonomilerini etkileyen küresel krizle (2009) ilgili olduğu söylenebilir.

İhracatın ithalatı karşılama oranı ise incelenen yıllar itibariyle çok fazla değişim göstermekle birlikte, sürekli olarak dengeyi tutturamayan bir yap1 sunmaktadır. Bu oranın son iki yıldır birkaç puan yükselmesi de $(\% 18,6$ 'dan \%21'e) Türkiye-BRICS ilişkilerinde küçük de olsa Türkiye lehine bir gelişme olarak değerlendirilebilir. 
Tablo 6. Türkiye'nin BRICS Ülkeleri ile İhracatının Görünümü (Bin \$)

\begin{tabular}{|c|c|c|c|c|c|c|c|c|c|c|}
\hline \multirow{2}{*}{ Y1llar } & \multicolumn{2}{|c|}{ Brezilya } & \multicolumn{2}{c|}{ Rusya } & \multicolumn{2}{c|}{ Hindistan } & \multicolumn{2}{c|}{ Cin } & Güney Afrika \\
\cline { 2 - 11 } & Miktar & $\begin{array}{c}\text { TR } \\
\text { \%'si }\end{array}$ & Miktar & $\begin{array}{c}\text { TR } \\
\% \text { 'si }\end{array}$ & Miktar & $\begin{array}{c}\text { TR } \\
\% \text { 'si }\end{array}$ & Miktar & $\begin{array}{c}\text { TR } \\
\% \text { 'si }\end{array}$ & Miktar & $\begin{array}{c}\text { TR } \\
\% \text { 'si }\end{array}$ \\
\hline 1996 & 43156 & 0,2 & 1510005 & 6,5 & 59390 & 0,3 & 65115 & 0,3 & 65516 & 0,3 \\
\hline 1997 & 47873 & 0,2 & 2056547 & 7,8 & 60826 & 0,2 & 44375 & 0,2 & 71204 & 0,3 \\
\hline 1998 & 43921 & 0,2 & 1348002 & 5,0 & 73571 & 0,3 & 38447 & 0,1 & 72912 & 0,3 \\
\hline 1999 & 33658 & 0,1 & 588664 & 2,2 & 120532 & 0,5 & 36649 & 0,1 & 58964 & 0,2 \\
\hline 2000 & 41679 & 0,2 & 643903 & 2,3 & 56047 & 0,2 & 96010 & 0,3 & - & - \\
\hline 2001 & 89818 & 0,3 & 924107 & 2,9 & 74373 & 0,2 & 199373 & 0,6 & - & - \\
\hline 2002 & 48979 & 0,1 & 1172039 & 3,3 & 72724 & 0,2 & 268229 & 0,7 & - & - \\
\hline 2003 & 50165 & 0,1 & 1367591 & 2,9 & 71365 & 0,2 & 504626 & 1,1 & - & - \\
\hline 2004 & 69355 & 0,1 & 1859187 & 2,9 & 136317 & 0,2 & 391585 & 0,6 & - & - \\
\hline 2005 & 103458 & 0,1 & 2377050 & 3,2 & 219869 & 0,3 & 549764 & 0,7 & - & - \\
\hline 2006 & 121882 & 0,1 & 3237611 & 3,8 & 222242 & 0,3 & 693038 & 0,8 & - & - \\
\hline 2007 & 229914 & 0,2 & 4726853 & 4,4 & 348229 & 0,3 & 1039523 & 1,0 & - & - \\
\hline 2008 & 318027 & 0,2 & 6843004 & 5,2 & 542730 & 0,4 & 1437204 & 1,1 & - & - \\
\hline 2009 & 388207 & 0,4 & 3189607 & 3,1 & 409202 & 0,4 & 1600296 & 1,6 & - & - \\
\hline 2010 & 614551 & 0,5 & 4628153 & 4,1 & 606081 & 0,5 & 2269175 & 2,0 & - & - \\
\hline 2011 & 883471 & 0,7 & 5992633 & 4,4 & 756082 & 0,6 & 2466316 & 1,8 & - & - \\
\hline 2012 & 1002759 & 0,7 & 6680777 & 4,4 & 791720 & 0,5 & 2833255 & 1,9 & - & - \\
\hline 2013 & 936096 & 0,6 & 6964209 & 4,6 & 586927 & 0,4 & 3600865 & 2,4 & - & - \\
\hline
\end{tabular}

Kaynak:http://www.tuik.gov.tr/PreIstatistikTablo.do?istab id=1548, erişim 09.01.2015. http://tuikapp.tuik.gov.tr/ , erişim 09.01.2015.

Not: Tüm \% hesaplamaları tarafımdan yapılmıştır.

Tablo 6 Türkiye BRICS ülkeleri ihracat ilişkilerini ülkeler bazında ayrı ayrı göstermektedir. Hem 1996 hem 2013 itibariyle Türkiye ihracat payının en yüksek olduğu ülke Rusya olmasına rağmen, bu oranın \%6,5'lerden \%4,6'lara gerilediği gözlenmektedir. $\mathrm{Bu}$ düşüşlerin özellikle Türkiye ve küresel odaklı krizlerin yarattığı talep daralması ile AB ve ABD'nin Türkiye üzerindeki siyasi ve ekonomik yaptırımları kaynaklı olduğu söylenebilir. 18 yıllık bu süreçte Güney Afrika ile olan ihracatın bittiği, buna karşılık Çin'e olan ihracat payının 8 kat arttığ1 (\%0,3'den \%2,4'e) dikkat çekmektedir. Kriz konjonktürünün Çin'e olan ihracatı çok fazla etkilemediği söylenebilir. Hindistan'a gerçekleştirilen ihracatta çok fazla bir artış görülmezken (\%0,3'den \%0,4'e), Brezilya'nın ihracat payının 3 kat arttı̆̆ da (\%0,2'den \%0,6'ya) görülmektedir.

Türkiye toplam ithalatı içerisinde en yüksek paya sahip olan BRICS ülkesinin, ihracatta da olduğu gibi, Rusya olduğunu görmekteyiz. Hatta Türkiye'nin Rusya'dan ithalatı 1996'dan bu yana yüzdesel olarak 2 kattan fazla (1996'da \%4,4, 2013'de \%10) artmıştır. Oysa Türkiye'nin Rusya'ya ihracatının Tablo 3'den de anlaşılacağı gibi- 18 yıllık süreç içerisinde yüzdesel olarak azaldığı görülmektedir. Bu durum Türkiye Rusya dış ticaretinde Türkiye aleyhine mevcut olan açığın büyüdüğünü anlatmaktadır.

Türkiye'nin Güney Afrika'dan olan ithalat 2000 yılından itibaren tamamen kesilirken, Brezilya'dan olan ithalat topluluk içerisindeki dağılıma göre azalma göstermiştir. Türkiye BRICS ticaretinde Çin'den yapılan ithalatın yüzdesel değeri 7 kattan fazla artarak (\%1,3'den \%9,8'e) Rusya ile yaklaşık aynı paya sahip hale gelmiştir. 
N. Kuşat / Gümrük Birliği Antlaşmasını Takip Eden Süreçte Türkiye-BRICS Dış Ticareti Yoğunlaşma Analizi

Tablo 7. Türkiye'nin BRICS Ülkeleri ile İthalatının Görünümü (Bin \$)

\begin{tabular}{|c|c|c|c|c|c|c|c|c|c|c|}
\hline \multirow{2}{*}{ Y1llar } & \multicolumn{2}{|c|}{ Brezilya } & \multicolumn{2}{|c|}{ Rusya } & \multicolumn{2}{c|}{ Hindistan } & \multicolumn{2}{c|}{ Cin } & \multicolumn{2}{c|}{ Güney Afrika } \\
\cline { 2 - 12 } & Miktar & $\begin{array}{c}\text { TR } \\
\% \text { 'si }\end{array}$ & Miktar & $\begin{array}{c}\text { TR } \\
\% \text { 'si }\end{array}$ & Miktar & $\begin{array}{c}\text { TR } \\
\% \text { 'si }\end{array}$ & Miktar & $\begin{array}{c}\text { TR } \\
\% \text { 'si }\end{array}$ & Miktar & $\begin{array}{c}\text { TR } \\
\% \text { 'si }\end{array}$ \\
\hline 1996 & 291705 & 0,7 & 1921139 & 4,4 & 258174 & 0,6 & 556492 & 1,3 & 210211 & 0,5 \\
\hline 1997 & 330111 & 0,7 & 2174258 & 4,5 & 300892 & 0,6 & 787457 & 1,6 & 183259 & 0,4 \\
\hline 1998 & 407373 & 0,9 & 2155006 & 4,7 & 276474 & 0,6 & 846134 & 1,8 & 152480 & 0,3 \\
\hline 1999 & 226200 & 0,6 & 2374133 & 5,8 & 243006 & 0,6 & 894813 & 2,2 & 123626 & 0,3 \\
\hline 2000 & 302505 & 0,6 & 3886583 & 7,1 & 449307 & 0,8 & 1344731 & 2,5 & - & - \\
\hline 2001 & 212121 & 0,5 & 3435673 & 8,3 & 354875 & 0,9 & 925620 & 2,2 & - & - \\
\hline 2002 & 236091 & 0,5 & 3891721 & 7,5 & 564463 & 1,1 & 1368317 & 2,7 & - & - \\
\hline 2003 & 401826 & 0,6 & 5451315 & 7,9 & 722855 & 1,0 & 2610298 & 3,8 & - & - \\
\hline 2004 & 566293 & 0,6 & 9033138 & 9,3 & 1046398 & 1,1 & 4476077 & 4,6 & - & - \\
\hline 2005 & 798576 & 0,7 & 12905620 & 11,1 & 1280473 & 1,1 & 6885400 & 5,9 & - & - \\
\hline 2006 & 934782 & 0,7 & 17806239 & 12,8 & 1579405 & 1,1 & 9669110 & 6,9 & - & - \\
\hline 2007 & 1172669 & 0,7 & 23508494 & 13,8 & 2299732 & 1,4 & 13234092 & 7,8 & - & - \\
\hline 2008 & 1423868 & 0,7 & 31364477 & 15,5 & 2457908 & 1,2 & 15658210 & 7,8 & - & - \\
\hline 2009 & 1105890 & 0,8 & 19450086 & 13,8 & 1902607 & 1,4 & 12676573 & 9,0 & - & - \\
\hline 2010 & 1347525 & 0,7 & 21600641 & 11,6 & 3409938 & 1,8 & 17180806 & 9,3 & - & - \\
\hline 2011 & 2074354 & 0,9 & 23952914 & 9,9 & 6498651 & 2,7 & 21693336 & 9,0 & - & - \\
\hline 2012 & 1770094 & 0,7 & 26625286 & 11,3 & 5843638 & 2,5 & 21295242 & 9,0 & - & - \\
\hline 2013 & 1408806 & 0,6 & 25064214 & 10,0 & 6367791 & 2,5 & 24685885 & 9,8 & - & - \\
\hline
\end{tabular}

Kaynak:http://www.tuik.gov.tr/PreIstatistikTablo.do?istab id=1548, erişim 09.01.2015.

http://tuikapp.tuik.gov.tr/, erişim 09.01.2015. Not: Tüm \% hesaplamaları tarafimdan yapılmıştır.

Dış ticarette ülke bazlı yoğunlaşmanın artması ihracat ve/veya ithalatta daha az sayıda ülkeyle ticari ilişkilerin gerçekleştirilmesi anlamına gelmektedir. Ürün bazlı yoğunlaşmanın artması ise, belli başlı ürünlerin ticaretinde meydana gelen artışı ifade eder. Türkiye'nin BRICS ülkeleri ile ticari ilişkilerindeki ürün bazlı yoğunlaşmayı görebilmek için Tablo 8'de SITC Rev3 Düzey 1'e (Uluslararası Standart Ticaret Sınıflaması) göre Türkiye-BRICS dış ticareti değerlendirilmiştir. Bu çalışma 18 yıllık bir dönemi kapsadığından ve SITC Rev3 sinıflama sistemi 10 farklı sinıflama grubundan oluştuğundan (180 ihracat ve 180 ithalat verisi anlamına gelmektedir), Tablo 8'de sadece Türkiye dış ticaretindeki payı yüksek olan ilk 3 ürün grubuna yer verilmiştir ${ }^{1}$.

\footnotetext{
${ }^{1}$ Tablo 8'in oluşturulma sistemi şu şekildedir: www.tuik.gov.tr internet sitesinden elde edilen 19962013 yılları STIC Rev3 dış ticaret verileri; her y1l için 10 ürün grubu gözetilerek hazırlanan geniş bir tabloya aktarılarak her grubun Türkiye dış ticaretindeki \% değerlerine ulaşılmıştır. Bu tablo çok kalabalık bir görünüme sahip olduğundan incelenen her yıl için en yüksek paya sahip ilk 3 grup seçilerek daha sade ve daha anlaşılabilir olan bu tabloya ulaşılmıştır.
} 
Tablo 8. SITC Rev3 Sınıflamasına Göre Türkiye - BRICS Dış Ticaretinde Lider Gruplar

\begin{tabular}{|c|c|c|c|c|c|c|c|}
\hline \multirow{2}{*}{$\begin{array}{c}\text { Yillar } \\
1996\end{array}$} & \multirow{2}{*}{$\begin{array}{r}\text { STIC Rev3* } \\
\text { Ürün Grubu } \\
\% \\
\%\end{array}$} & \multicolumn{3}{|c|}{ İhracatta Önde Giden 3 Grup } & \multicolumn{3}{|c|}{ İthalatta Önde Giden 3 Grup } \\
\hline & & $\begin{array}{r}5 \\
14,1\end{array}$ & $\begin{array}{r}2 \\
9,3\end{array}$ & $\begin{array}{r}0 \\
8,7\end{array}$ & $\begin{array}{r}3 \\
15,4 \\
\end{array}$ & $\begin{array}{r}2 \\
12,4\end{array}$ & $\begin{array}{r}6 \\
12,2 \\
\end{array}$ \\
\hline 1997 & $\begin{array}{r}\text { Ürün Grubu } \\
\%\end{array}$ & $\begin{array}{r}5 \\
16,1\end{array}$ & $\begin{array}{r}8 \\
12,2\end{array}$ & $\begin{array}{r}0 \\
9,8\end{array}$ & $\begin{array}{r}3 \\
15,5\end{array}$ & $\begin{array}{r}2 \\
14,5\end{array}$ & $\begin{array}{r}6 \\
13,5\end{array}$ \\
\hline 1998 & $\begin{array}{r}\text { Ürün Grubu } \\
\%\end{array}$ & $\begin{array}{r}4 \\
14,0 \\
\end{array}$ & $\begin{array}{r}5 \\
12,2 \\
\end{array}$ & $\begin{array}{r}0 \\
8,6 \\
\end{array}$ & $\begin{array}{r}2 \\
18,1 \\
\end{array}$ & $\begin{array}{r}3 \\
18,1 \\
\end{array}$ & $\begin{array}{r}6 \\
14,2 \\
\end{array}$ \\
\hline 1999 & $\begin{array}{r}\text { Ürün Grubu } \\
\%\end{array}$ & $\begin{array}{r}2 \\
9,6 \\
\end{array}$ & $\begin{array}{r}5 \\
6,1 \\
\end{array}$ & $\begin{array}{r}0 \\
5,7 \\
\end{array}$ & $\begin{array}{r}3 \\
21,6 \\
\end{array}$ & $\begin{array}{r}2 \\
20,3 \\
\end{array}$ & $\begin{array}{r}6 \\
15,3 \\
\end{array}$ \\
\hline 2000 & $\begin{array}{r}\text { Ürün Grubu } \\
\%\end{array}$ & $\begin{array}{r}5 \\
7,8 \\
\end{array}$ & $\begin{array}{r}2 \\
7,6 \\
\end{array}$ & $\begin{array}{r}1 \\
5,7 \\
\end{array}$ & $\begin{array}{r}3 \\
23,4 \\
\end{array}$ & $\begin{array}{r}6 \\
18,3 \\
\end{array}$ & $\begin{array}{r}2 \\
17,0 \\
\end{array}$ \\
\hline 2001 & $\begin{array}{r}\text { Ürün Grubu } \\
\%\end{array}$ & $\begin{array}{r}2 \\
10,4 \\
\end{array}$ & $\begin{array}{r}5 \\
9,2 \\
\end{array}$ & $\begin{array}{r}0 \\
5,7 \\
\end{array}$ & $\begin{array}{r}3 \\
30,7 \\
\end{array}$ & $\begin{array}{r}6 \\
14,9 \\
\end{array}$ & $\begin{array}{r}2 \\
11,8 \\
\end{array}$ \\
\hline 2002 & $\begin{array}{r}\text { Ürün Grubu } \\
\%\end{array}$ & $\begin{array}{r}2 \\
12,5 \\
\end{array}$ & $\begin{array}{r}5 \\
9,5 \\
\end{array}$ & $\begin{array}{r}0 \\
6,3 \\
\end{array}$ & $\begin{array}{r}3 \\
30,0 \\
\end{array}$ & $\begin{array}{r}6 \\
14,5 \\
\end{array}$ & $\begin{array}{r}1 \\
14,0 \\
\end{array}$ \\
\hline 2003 & $\begin{array}{r}\text { Ürün Grubu } \\
\%\end{array}$ & $\begin{array}{r}2 \\
16,4 \\
\end{array}$ & $\begin{array}{r}5 \\
10,1 \\
\end{array}$ & $\begin{array}{r}0 \\
6,5 \\
\end{array}$ & $\begin{array}{r}3 \\
32,3 \\
\end{array}$ & $\begin{array}{r}1 \\
21,5 \\
\end{array}$ & $\begin{array}{r}6 \\
16,6 \\
\end{array}$ \\
\hline 2004 & $\begin{array}{r}\text { Ürün Grubu } \\
\%\end{array}$ & $\begin{array}{r}2 \\
15,2 \\
\end{array}$ & $\begin{array}{r}5 \\
11,2 \\
\end{array}$ & $\begin{array}{r}0 \\
7,2 \\
\end{array}$ & $\begin{array}{r}3 \\
39,7 \\
\end{array}$ & $\begin{array}{r}6 \\
19,4 \\
\end{array}$ & $\begin{array}{r}2 \\
18,5 \\
\end{array}$ \\
\hline 2005 & $\begin{array}{r}\text { Ürün Grubu } \\
\%\end{array}$ & $\begin{array}{r}2 \\
20,2 \\
\end{array}$ & $\begin{array}{r}5 \\
11,0\end{array}$ & $\begin{array}{r}0 \\
6,6 \\
\end{array}$ & $\begin{array}{r}3 \\
42,3 \\
\end{array}$ & $\begin{array}{r}1 \\
24,7\end{array}$ & $\begin{array}{r}8 \\
21,9 \\
\end{array}$ \\
\hline 2006 & $\begin{array}{r}\text { Ürün Grubu } \\
\%\end{array}$ & $\begin{array}{r}2 \\
23,2 \\
\end{array}$ & $\begin{array}{r}5 \\
11,6 \\
\end{array}$ & $\begin{array}{r}0 \\
7,4 \\
\end{array}$ & $\begin{array}{r}3 \\
44,7 \\
\end{array}$ & $\begin{array}{r}8 \\
24,9 \\
\end{array}$ & $\begin{array}{r}6 \\
23,3 \\
\end{array}$ \\
\hline 2007 & $\begin{array}{r}\text { Ürün Grubu } \\
\%\end{array}$ & $\begin{array}{r}2 \\
31,3 \\
\end{array}$ & $\begin{array}{r}5 \\
12,3 \\
\end{array}$ & $\begin{array}{r}0 \\
9,4 \\
\end{array}$ & $\begin{array}{r}3 \\
51,3 \\
\end{array}$ & $\begin{array}{r}8 \\
25,6 \\
\end{array}$ & $\begin{array}{r}6 \\
25,4 \\
\end{array}$ \\
\hline 2008 & $\begin{array}{r}\text { Ürün Grubu } \\
\%\end{array}$ & $\begin{array}{r}2 \\
40,1 \\
\end{array}$ & $\begin{array}{r}5 \\
12,6 \\
\end{array}$ & $\begin{array}{r}0 \\
9,6 \\
\end{array}$ & $\begin{array}{r}3 \\
47,7 \\
\end{array}$ & $\begin{array}{r}6 \\
28,1 \\
\end{array}$ & $\begin{array}{r}1 \\
27,7 \\
\end{array}$ \\
\hline 2009 & $\begin{array}{r}\text { Ürün Grubu } \\
\%\end{array}$ & $\begin{array}{r}2 \\
46,3 \\
\end{array}$ & $\begin{array}{r}5 \\
10,8 \\
\end{array}$ & $\begin{array}{r}0 \\
8,9 \\
\end{array}$ & $\begin{array}{r}3 \\
49,6 \\
\end{array}$ & $\begin{array}{r}1 \\
30,8 \\
\end{array}$ & $\begin{array}{r}8 \\
28,8 \\
\end{array}$ \\
\hline 2010 & $\begin{array}{r}\text { Ürün Grubu } \\
\%\end{array}$ & $\begin{array}{r}2 \\
48,5 \\
\end{array}$ & $\begin{array}{r}5 \\
12,1 \\
\end{array}$ & $\begin{array}{r}0 \\
9,7\end{array}$ & $\begin{array}{r}3 \\
43,2 \\
\end{array}$ & $\begin{array}{r}8 \\
33,8 \\
\end{array}$ & $\begin{array}{r}1 \\
25,4 \\
\end{array}$ \\
\hline 2011 & $\begin{array}{r}\text { Ürün Grubu } \\
\%\end{array}$ & $\begin{array}{r}2 \\
64,4 \\
\end{array}$ & $\begin{array}{r}5 \\
11,9 \\
\end{array}$ & $\begin{array}{r}0 \\
9,0 \\
\end{array}$ & $\begin{array}{r}3 \\
36,4 \\
\end{array}$ & $\begin{array}{r}8 \\
34,6 \\
\end{array}$ & $\begin{array}{r}6 \\
25,4 \\
\end{array}$ \\
\hline 2012 & $\begin{array}{r}\text { Ürün Grubu } \\
\%\end{array}$ & $\begin{array}{r}2 \\
50,5\end{array}$ & $\begin{array}{r}5 \\
11,6\end{array}$ & $\begin{array}{r}0 \\
8,6\end{array}$ & $\begin{array}{r}3 \\
35,8\end{array}$ & $\begin{array}{r}4 \\
34,5\end{array}$ & $\begin{array}{r}8 \\
33,0\end{array}$ \\
\hline 2013 & $\begin{array}{r}\text { Ürün Grubu } \\
\%\end{array}$ & $\begin{array}{r}2 \\
54,8 \\
\end{array}$ & $\begin{array}{r}5 \\
11,1\end{array}$ & $\begin{array}{r}0 \\
8,6\end{array}$ & $\begin{array}{r}3 \\
35,3\end{array}$ & $\begin{array}{r}8 \\
32,2\end{array}$ & $\begin{array}{r}4 \\
30,5\end{array}$ \\
\hline
\end{tabular}

Kaynak:http://www.tuik.gov.tr/PreIstatistikTablo.do?istab id=1548, erişim 09.01.2015. http://tuikapp.tuik.gov.tr//, erişim 09.01.2015.

Not: Tüm \% hesaplamaları tarafımdan yapılmıştır.

*SITC Rev 3 Düzey1 Ürün Grubu İsimleri

0 Canlı Hayvanlar ve Gıda Maddeleri

1 İçki ve Tütün

2 Akaryakıt Hariç Yenilmeyen Hammaddeler

3 Mineral Yakıtlar, Yağlar ve Alkali Ürünler

4 Hayvansal, Bitkisel Katı ve Sıvı Yağlar, Mumlar

5 Başka Yerde Belirtilmeyen Kimya Sanayi ve Buna Bağlı Sanayi Ürünleri

6 Başlıca Sınıflara Ayrılan İşlenmiş Mallar

7 Makinalar ve Ulaştırma Araçları

8 Çeşitli Mamul Eşya

9 SITC'da Sınıflandırılmamış Eşyalar (Tedavülde Olmayan paralar, Parasal Tabanlı Altınlar)

Türkiye'nin BRICS ülkeleri ihracatında SITC Rev3 sınıflamasına göre önde gelen ilk üç ürün grubunun, izlenen 18 yılın 15'i için hiç değişmeden sürdürüldügü gözlenmektedir. 2001 yılından itibaren bu üç ürün grubu için ağırlık sıralamasında da bir değişme olmamıştır. 1996 yılında Türkiye'nin "Akaryakıt Hariç Yenilmeyen Hammaddeler" ürün grubundaki ihracatı \% 9,3'lük payıyla BRICS ülkelerine gerçekleştirilen en yüksek 2. sıradaki ihracat ürün grubunu oluştururken, 2013'de yaklaşık 6 kat $(5,9)$ artarak \%54,8'lik payla 1. sıraya yerleşmiştir. 1996'da \%14,1'lik payla BRICS ülkelerine en yoğun ihracatın 
N. Kuşat / Gümrük Birliği Antlaş̧masını Takip Eden Süreçte Türkiye-BRICS Dış Ticareti Yoğunlaşma Analizi gerçekleştirildiği "Başka Yerde Belirtilmeyen Kimya Sanayi ve Buna Bağlı Sanayi Ürünleri" ürün grubunun pay1, 2013'de \%11,1'lik bir paya gerileyerek, Türkiye toplam ihracatında 2. sıraya düşmüştür. 1996 yılında 3. en fazla ihracat payına sahip $(\% 8,7)$ "Canlı Hayvanlar ve G1da Maddeleri” ürün grubu ise, \%8,6’lık ihracat payı ile sıralamadaki yerini günümüzde de korumaktadır.

Türkiye-BRICS ithalatındaki ürün bazlı yoğunlaşma, incelenen 18 y1llık süreç için ihracattaki kadar stabil gerçekleşmemiştir. Fakat bu süreçte, 1998 y1lı hariç, Türkiye-BRICS ithalatında "Mineral Yakıtlar, Yağlar ve Alkali Ürünler" grubu en önde gelen ürün grubu olarak liderliğini korumuştur. 1996-2001 arasında BRICS ithalatında "Başlıca Sınıflara Ayrılan İşlenmiş Mallar" ve "Akaryakıt Hariç Yenilmeyen Hammaddeler" ürün grupları dikkat çekerken, 2001-2010 döneminde "İçki ve Tütün”, 2005-2013 döneminde ise "Çeşitli Mamul Eşya" ürün grupları ilk üç sırada yer almaya başlamıştır.

Tablo 8'i Türkiye-BRICS ticaretinde ürün bazlı yoğunlaşma açısından değerlendirirsek, ihracattaki yoğunlaşmanın "Akaryakıt Hariç Yenilmeyen Hammaddeler" ürün grubunda oldukça etkin bir şekilde kendisini gösterdiğini söyleyebiliriz (2013 itibariyle \%54,8'lik ihracat pay1). Türkiye belirtilen bu gruptaki ihracatının yarıdan fazlasını BRICS ülkelerine gerçekleştirmektedir ki bu rakam oldukça yüksek ve anlamlıdır. Tablo 8'de ki 2013 ithalat verilerine baktığımızda ise; ürün bazlı yoğunlaşmada tek bir ürün grubu yerine üç farklı ürün grubunun birbirine yakın değerlerle yer aldıkları görülmektedir. Bu ürün gruplar1; "Mineral Yakıtlar, Yağlar ve Alkali Ürünler" (\%35,3), "Çeşitli Mamul Eşya" (32,2) ve "Hayvansal, Bitkisel katı ve Sıvı Yağlar, Mumlar $(\% 30,5)$ şeklindedir.

\section{Sonuç}

Türkiye'nin liberal dış ticaret anlayışını benimseyerek, dünyadaki kapitalist yapılanmaya uyum sağlama sürecinde yaşadığ1 iki önemli gelişme vardır: Bunlardan bir tanesi 24 Ocak Kararları olarak bilinen 1980 tarihli ekonomik istikrar programı, ikincisi ise 1 Ocak 1996 itibariyle yürürlüğe giren Türkiye-AB GB Antlaşmasıdır. Bu iki gelişme Türk dış ticaretinin içinde bulunduğu değişim ve gelişim sürecinin temel yapı taşlarını oluşturmaktadır.

$\mathrm{Bu}$ çalışma GB Antlaşması sonrasında Türkiye'nin BRICS ülkeleri ile gerçekleştirdiği ticari ilişkilerdeki gelişmeleri ele almaktadır. Türkiye ile AB 28 ülkeleri arasındaki GB antlaşması entegrasyon içerisinde ticaret yaratıcı etkiler ortaya koymasına rağmen; bu gelişmelerin BRICS ülkeleriyle olan ticareti kısıtlayıcı etkiler yaratmadığı; hatta bu ilişkilerin GB sonrası AB 28 ülkeleriyle olan ticarete kıyasla daha da yoğunlaştı̆̆ı gözlenmiştir.

Türkiye-BRICS arasında gerçekleşen ticarette, bu ticari ilişkinin BRICS ülkeleri lehine bir yapı sergilediği anlaşılmaktadır. İncelenen 18 yıllık süreçte ticaret hacminin 1998, 2001 ve 2009 yılları hariç hep yükselme eğilimi gösterdiği ve 2001 ve 2009 yılları hariç dış ticaret açıklarının büyüdüğ̈̈ gözlenmektedir. Belirtilen yıllar için ortaya çıkan daraltıcı etkilerin bazen Türkiye'nin yaşadığı krizle (1998 ve 2001), bazen de tüm dünya ekonomilerini etkileyen küresel krizle 
(2009) ilgili olduğu söylenebilir. İhracatın ithalatı karşılama oranı ise incelenen yıllar itibariyle sürekli 1'in altında kalmıştır.

Hem 1996 hem 2013 itibariyle Türkiye ihracat payının en yüksek olduğu ülke Rusya olmasına rağmen, bu oranın $\% 6,5^{\prime}$ lerden $\% 4,6^{\prime}$ lara gerilediği gözlenmektedir. $\mathrm{Bu}$ düşüşlerin özellikle Türkiye ve küresel odaklı krizlerin yarattığı talep daralması ile $A B$ ve ABD'nin Türkiye üzerindeki siyasi ve ekonomik yaptırımları kaynaklı olduğu söylenebilir. 18 yıllık bu süreçte Güney Afrika ile olan ihracatın bittiği dikkat çekerken, özellikle Çin'e olan ihracat payının 8 kat arttığ $1 \% 0,3$ 'den \%2,4'e) ve kriz konjonktürünün Çin'e olan ihracatı çok fazla etkilemediği dikkat çekmektedir. Çin ve Hindistan'dan olan ithalatın artma eğilimi gösterdiği, buna karşılık BRICS içerisinde en çok ithalat yapılan Rusya ile gerçekleştirilen ticaretin istikrarsız bir yapı sergilemesi de dikkat çekmektedir. Ayrıca Rusya, BRICS içerisinde olup Türkiye'nin toplam ithalat ve ihracatı içerisinde en çok ticaret yapılan ilk beş ülke arasında yer almasına rağmen, ihracat azalışları ve ithalat artışları ile Türk dış ticaretindeki açıklar üzerinde de etkin bir rol oynamaktadır. Buna rağmen elde ettiğimiz bulgular Türkiye BRICS ticari ilişkilerinde Rusya'nın mevcut ağırlıklı payını, Çin'in ele geçirmek üzere olduğunu göstermektedir.

Özetle, Türkiye dış ticaretindeki ülke bazlı yoğunlaşma Rusya'dan Çin ve Hindistan'a doğru kaymaktadır. AB'nin BRICS ile ticaretinde de aynı durumun olduğu gözlenmektedir. Hatta Rusya, AB'nin BRICS'e ihracatındaki üstünlüğünü 2008'den itibaren Çin'e devretmekle kalmamış, AB'nin Rusya'ya ihracat ve ithalat1 2012'den sonra azalışa geçmiştir. Bu gelişmede de AB, ABD ve Rusya arasında yaşanan soğuk savaşın etkileri olduğu aşikardır.

İhracat açısından ürün bazlı yoğunlaşmada "Akaryakıt Hariç Yenilmeyen Hammadde" ürün grubu hiç koşulsuz liderliğini sürdürmektedir. Türkiye'nin bu ürün grubunda belirli bir uzmanlaşmaya sahip olduğu sonucundan yola çıkılarak, diğer ülkelerle olan ticari ilişkilerinde bu performansını kullanarak bir üstünlük yakalamasının muhtemel olduğu söylenebilir. İthalatta ortaya çıkan ürün bazlı yoğunlaşmada ise tek bir ürün grubu yerine üç farklı ürün grubunun eşit düzeyde öne çıktığı görülmektedir. Bu ürün grupları; "Mineral Yakıtlar, Yağlar ve Damıtılmasından Elde Edilen Ürünler" (\%35,3), "Çeşitli Mamul Eşya" (32,2) ve "Hayvansal, Bitkisel katı ve Sıvı Yağlar, Mumlar (\%30,5) şeklindedir.

AB'nin BRICS'den gerçekleştirdiği ithalat ve ihracat işlemlerinde, Türkiye ticaretinde olduğu gibi, benzer ürünlerin alım satımının yapıldığı dikkat çekmektedir. ${ }^{2}$ AB BRICS'den ağırlıklı olarak tarımsal ürünler, yakıtlar ve maden ürünleri ithal etmektedir. İhracatın da ise öne çıkan ürünler mamul ve yarı mamul mallar, makine ve ekipmanlar ve kimyasallar şeklinde kendini göstermektedir. Türkiye'nin BRICS'e ihracatında da kimyasalların ağırlıklı yapısı gözlenmektedir.

\footnotetext{
${ }^{2}$ Bu konuda ayrıntılı bilgi için bknz. BORTA, L., (2013), "The Current BRICS Trade Barriers on EU's Exports”, CES Working Papers, Volume V, Issue 3, pp.344-358.
} 
Sandalc1lar'ın (2012:4171) Türkiye-BRIC arasındaki ticari potansiyeli araştırdığı ve 2002-2209 yıllarını kapsayan çalışma sonuçları; Türkiye'nin Brezilya, Hindistan ve Çin'le ticari potansiyelinin altında, Rusya ile ticari potansiyelinin üzerinde diş ticaret gerçekleştirdiğini göstermektedir. Bu bağlamda bu iki çalışma sonuçlarının birlikte değerlendirilerek bir Türkiye-BRICS ticari politikasının oluşturulması, Türkiye ticareti için olumlu sonuçlar doğurabilir.

Çalışma sonucunda BRICS'in son üyesi olan Güney Afrika ile Türkiye arasındaki ticari ilişkilerin 2000 yılından itibaren sekteye uğradığ son bulduğu gözlenmektedir. Sonuç oldukça dikkat çekici olmasına rağmen, bu konunun değerlendirilmesi bir başka çalışmaya bırakılmıştır.

\section{Kaynaklar}

AKAL, M. (2008), "Ortadoğu Sınır Ülkeleriyle Dış Ticaret Yoğunlaşması ve Yapısal Değişim” Gaziantep Üniversitesi Sosyal Bilimler Dergisi, 7(2), ss.271-296.

ALTUNDAL, V. (2014), "Bölgesel Ticaret Anlaşmalarının 2008 Küresel Ekonomik Kriz Sonrası Türkiye "nin Dış Ticaret Açığına Etkisi ve Gümrük Birliği Anlaşması Örneği”, Afyon Kocatepe Üniversitesi, Sosyal Bilimler Enstitüsü, Yüksek Lisans Tezi, Eylül 2014.

ATABAY BAYRAKTAR, R. (2012), "Türkiye ve BRIC Ülkeleri Arasındaki Ticaret Hacminin Belirleyicileri: Panel Çekim Modeli Analizi”, İstanbul Ticaret Üniversitesi Sosyal Bilimler Dergisi, Y11: 11, Say1: 21, Bahar, ss.403-424.

BALASSA, B. (1961), The Theory of Economic Integration, Richard D. Irwin, Inc, Homewood Illinois.

BORTA, L. (2013), “The Current BRICS Trade Barriers on EU's Exports”, CES Working Papers, Volume V, Issue 3, pp.344-358.

CANElA, M. A.; COLLAZO, E. P. and SANTISO, J. (2006), "Capital Flows to BRICs Countries: Fundamentals or Just Liquidity?", Presented at the Latin American and Caribbean Economic Association Conference, Mexico, DF, November 2-4 2006 (unpublished).

ÇAK, D. ve ÇAK, M. (2007), Gümrük Birliği'nin Getirdikleri ve Götürdükleri: Dış Ticaret Vergileri ve İhracat Gelirleri Analizi, İstanbul Ticaret Odas1, Yayın No: 2007-68, İstanbul.

ÇELIK, K. (2012), Uluslararası İktisat, Derya Kitabevi, 5. Baskı.

ÇOLPAN NART, E. (2010), “Gümrük Birliği'nin Türkiye Dış Ticareti Üzerine Etkileri: Panel Veri Analizi”, Journal of Yaşar University, 17(5), ss. 2874-2885.

DOĞAN, S. ve SOYYİĞİT KAYA, S. (2011), "Gümrük Birliği Sonrasında (1996-2009) Türkiye'nin AB ile Dış Ticaretinin Ülke ve Fasıl Bazlı Yoğunlaşma Analizi”, Ekonometri ve İstatistik, Say1:14, ss.1-18.

ERKAN, B. (2012), BRIC Ülkeleri ve Türkiye İhracat Uzmanlaşma ve Rekabet Düzeylerinin Karşılaş̧ırmalı Analizi, Ekonomik ve Sosyal Araştırmalar Dergisi, Bahar, Cilt: 8, Yı1: 8, Say1:1, ss.101-131.

ERTEKIN, M. (2005), Sektörler İtibariyle Üretim-Dış Ticaret İlişsisi ve Rekabet Koşulları, Dış Ticaret Müsteşarlığı Araştırma Raporu, Ankara.

FALCIOĞLU, P. VE AKGÜNGÖR, S. (2008), "Regional Specialization and Industrial Concentration Patterns in the Turkish Manufacturing Industry: An Asseement fort he 1980-2000 Period1", Regional Studies Association Academic Papers, pp.303-323.

GÖKDEMIR, L. ve KARAMAN, E. (2008), “Onuncu Yılında Gümrük Birliği: Ne Beklendi? Ne Gerçekleşti?”, Fırat Üniversitesi Sosyal Bilimler Dergisi, C.18, S.2, ss.277-296.

GÜNDÜZ, O. ve ESENGÜN, K. (2007), “Gümrük Birliğinin Türkiye'nin Avrupa Birliği (15) İle Dış Ticareti Üzerine Etkileri”, GOÜ, Ziraat Fakültesi Dergisi, 24 (1), ss.43-39. 
HITT, M.A., Lİ,H. and WORTHINGTON,W.J. (2005), "Emerging Markets as Learning Laboratories: Learning Behaviors of Local Firms and Foreign Entrants in Different Institutional Contexts", Management and Organization Review, Vol: 1, Issue:3, pp. 353380.

KALAYCI, C. ve ARTAN, S. (2010), “Gümrük Birliğinin Türkiye'nin Dış Ticaretine Etkileri: Panel Veri Analizi”, Dumlupınar Üniversitesi Sosyal Bilimler Dergisi, Say1:27, Ağustos 2010, ss.301-314.

KARLUK, S. R. (2013), Uluslararası Ekonomi Teori-Politika, 10. Baskı, Beta Yayınları, İstanbul.

KIZILTAN, A., ERSUNGUR, M. ve POLAT, Ö. (2008), “Gümrük Birliği'nin Türkiye'nin Avrupa Birliği İle İhracat ve İthalatına Etkisi”, Atatürk Üniversitesi İktisadi ve İdari Bilimler Fakültesi Dergisi, Cilt:22, Ocak 2008, Say1:1, ss.83-99.

KÖSEKAHYAOĞLU, L. (2007), "Türkiye Dış Ticaretinde Ürün ve Ülke Bazında Yoğunlaşma: 1980-2005 Dönemi Üzerine Karşılaştırmalı Bir Analiz”, İstanbul Üniversitesi Siyasal Bilgiler Fakültesi Dergisi, No:36, Mart 2007, ss.15-34.

KÖSEKAHYAOĞLU, L. (2012), Dış Ticaret ve Rekabet Gücü 1923-2011, Alter Yayınc1lı, Ankara.

KRUGMAN, P. (1986), Strategic Trade Policy and the New International Economics, Paul R. Krugman, (ed.) Cambridge (Mass):MIT Press, Massachusetts USA, pp.2-22.

KÜÇÜKKİREMITÇi, O. KARACA, M. E. ve EŞIYOK, B. A. (2010), Türkiye'nin İhracatında Öne Çıkan Sektörlerde Temel Pazar Ülkeler, Rakipler ve Rekabet Gücü, Türkiye Kalkınma Bankası A.Ş., Ekonomik ve Sosyal Araştırmalar Müdürlüğü, Şubat 2010, Ankara.

LALL, S. (2000), "Turkish Performance in Exporting Manufactures: A Comperative Structural Analysis", QEH Working Paper Series, No:47.

MORGIL, O. (2000), "The Impact of Trade Liberalization: Turkey's Experience with the Customs Union”, Hacettepe Üniversitesi İktisadi ve İdari Bilimler Fakültesi Dergisi, 18(2), ss. 189197.

O'NEILLL, J.; WILLSON, D.; PURUSHOTHAMAN, R. and STUPNYTSKA, A. (2005), "How Solid are the BRICs", Global Economics, Paper No. 1341, Goldman Sachs, December.

SANDALCILAR, A.R. (2012), “Türkiye'nin BRIC Ülkeleriyle Ticari Potansiyeli: Panel Çekim Modeli Yaklaşımı”, Journal of Yaşar University, 25(7), pp. 4164-4175.

SEYMEN, D. (2009), “Gümrük Birliği, Türkiye'nin AB ile Ticaretinde Ülke Yoğunlaşmasını Değiştirdi mi?”, Süleyman Demirel Üniversitesi İ̈BF Dergisi, C.14, S.1, ss.199-220.

SCHILLER, B. (2011), "Beyond the BRICS", Financial Management, March-2011, pp.27-30.

SEYIDOĞLU, H. (2003), Uluslararası İktisat Teori, Politika ve Uygulama, Güzem Yayınları, İstanbul.

SIMON, J. P. (2011), "The ICT Landscape in BRICS Countries: Brazil, India, China”, European Commission Joint Research Centre Institute for Prospective Technological Studies; Luxembourg: Publications Office of the European Union.

SRINIVASAN, T. N. (2014), "BRICS and the EU: An Oxymoron? (Panel 3)", CESifo Forum, 4/2014 (December).

STANDARD\&POORS, (2009), "BRIC by Name, BRIC by Nature?", Ratings Direct.

TEMIZ, D. (2009), "Gümrük Birliği ile Birlikte Türkiye'nin Dış Ticaretinde Yapısal Değişmeler Oldu mu?", Ankara Avrupa Çalışmaları Dergisi, Cilt:8, No:1, ss. 115-138.

TOGAN, S. (2000), "Effects of a Turkey-Eurepean Union Customs Union and Prospects for the Future", Russian and East Eurepean Finance and Trade, 36(4), pp. 5-25.

VAN AGTMAEL, A. (2012) “Think Again: The BRICS”, Foreign Policy, November-2012, pp. 7679.

WILSON, D. AND PURUSHOTHAMAN, R. (2003), "DreamingWith BRICs: The Path to 2050", Global Economics, Paper No: 99, 1st October, Goldman Sachs.

WILSON, D.; AHMED, S. and A. KELSTON, (2010), "Is This the 'BRICS Decade", Goldman Sachs, May 2010.

YILDIZ, R. ve DELİCE, G. (2001), “1990 Sonrasında Türkiye İhracatındaki Yapısal Değişimler Üzerine Gözlemler”, Dokuz Eylül Üniversitesi İsletme Fakültesi Dergisi, 2 (2), 101-127. 
N. Kuşat / Gümrük Birliği Antlaşmasını Takip Eden Süreçte Türkiye-BRICS Dış Ticareti Yoğunlaşma Analizi YU, Y. N. (2014), “Trade Remedies: Chine in the BRICS", Journal of World Trade, 12/2014, pp. 1247-1277.

ZHITAO, D. (2011), “BRICS Power”, Beijing Review, updated April 25, 2011.

İnternet Siteleri

http://www.tuik.gov.tr/PreIstatistikTablo.do?istab id=1548, erişim 09.01.2015.

http://tuikapp.tuik.gov.tr/ , erişim 09.01.2015.

http://www.tuik.gov.tr/UstMenu.do?metod=temelist , erişim 11.01.2015.

ec.europa.eu/eurostat/web/international_trade/data/database, erişim 08.05.2015. 